\title{
KOLEGIALNOŚĆ I SYNODALNOŚĆ W KOŚCIELE
}

Kolegialność biskupów w Kościele, widziana w kontekście odnowionej eklezjologii, nowego rozumienia funkcji biskupa oraz relacji biskupów do Ojca Świętego, stała się w ciągu ostatniego półwiecza ważnym narzędziem realizowania reform Soboru Watykańskiego II. Jedną z instytucji, która ma podtrzymywać ducha kolegialności doświadczanego podczas Soboru, jest Synod Biskupów, stworzony przez Pawła VI 15 września 1965, krótko przed ukończeniem obrad soborowych, za pomocą motu proprio Apostolica sollicitudo. Dla wszystkich posoborowych papieży: Pawła VI, Jana Pawła II, Benedykta XVI i Franciszka, Synod Biskupów był ważną instytucją doradczą w służbie posoborowej odnowy Kościoła.

Chciałbym przypomnieć w tym miejscu przemówienie wygłoszone przez papieża Franciszka 17 października 2015 roku podczas obrad XIV Zwyczajnego Zgromadzenia Ogólnego Synodu Biskupów poświęconego rodzinie. Bezpośrednim kontekstem tego przemówienia była 50. rocznica powołania instytucji Synodu Biskupów przez papieża Pawła VI. Co ważne Ojciec Święty Franciszek połączył temat kolegialności biskupów i misji Synodu Biskupów z tematem synodalności w Kościele ${ }^{1}$.

W swoim przemówieniu, Papież oparł się na wypowiedzi św. Jana Chryzostoma: „Kościól i Synod są synonimami”, aby podkreślić, że najbardziej fundamentalnym źródłem synodalności Kościoła jest chrzcielne namaszczenie wszystkich chrześcijan, które umożliwia istnienie zmysłu wiary (sensus fidei) Ludu Bożego. Mówi o tym Sobór Watykański II w Konstytucji Dogmatycznej o Kościele Lumen gentium:

Papież Franciszek, Discorso del Santo Padre Francesco, [w:] Commemorazione del 50.mo anniversario dell'Istituzione del Sinodo dei Vescovi: Discorso del Santo Padre Francesco, „Bollettino Sala Stampa della Santa Sede” 17.10.2015. 
Ogół wiernych, mających namaszczenie od Świętego (por. 1 J 2, 20. 27), nie może zbłądzić w wierze i tę szczególną swoją właściwość ujawnia przez nadprzyrodzony zmysł wiary (sensus fidei) całego ludu, gdy poczynając od biskupów aż po ostatniego z wiernych świeckich ujawnia on swą powszechną zgodność w prawach wiary i obyczajów².

Przekonanie, że Bóg prowadzi Kościół przemawiając do wszystkich ochrzczonych, było u źródeł decyzji papieża Franciszka, aby w procesie przygotowania dwóch Synodów Biskupów o rodzinie w latach 2014-2015 przeprowadzić szerokie konsultacje przedsynodalne także wśród osób świeckich. Zmartwychwstały Pan prowadzi swój Kościół mówiąc do wszystkich ochrzczonych; stąd też, w celu rozpoznania woli Bożej potrzebny jest dialog w Kościele i słuchanie siebie nawzajem:

Kościół synodalny to Kościół, który słucha w świadomości, że słuchanie to więcej niż tylko słyszenie. Chodzi o wzajemne słuchanie, gdzie każdy może się czegoś nauczyć. Lud wierny, Kolegium Biskupów, Biskup Rzymu: wszyscy słuchają siebie nawzajem i wszyscy słuchają Ducha Świętego, „Ducha Prawdy” (J 14, 17), aby usłyszeć to, co „mówi do Kościołów” (Ap 2, 7). Synod Biskupów jest punktem zbieżności tego procesu słuchania przeprowadzonego na każdym poziomie życia Kościoła ${ }^{3}$.

Papież wskazał na poszczególne etapy tego procesu synodalnego słuchania: zaczyna się od słuchania Ludu Bożego, który na mocy konsekracji chrzcielnej uczestniczy w funkcji prorockiej Chrystusa ${ }^{4}$. Potem następuje etap słuchania pasterzy, szczególnie Ojców Synodu, „autentycznych stróżów, interpretatorów i świadków wiary całego Kościoła, którą muszą ostrożnie odróżnić od zmieniających się prądów opinii publicznej”. Kulminacją procesu synodalnego słuchania jest słuchanie Biskupa Rzymu, który jest wezwany do mówienia jako „pasterz i nauczyciel wszystkich chrześcijan"5; nie chodzi o jego osobiste poglądy, ale o świadectwo wiary całego Kościoła (fides totius Ecclesiae). Tak rozumiana synodalność ma cechować cały Kościół i wszystkie jego poziomy: diecezje z synodami diecezjalnymi i różnymi formami konsultacji i kolegialności, parafie $z$ radami duszpasterskimi, ekonomicznymi, i inne. Papież Franciszek podkreślił, że wszyscy chrześcijanie są wezwani do tworzenia takiego synodalnego Kościoła; będzie on miał znaczenie przykładu i nowego standardu w świecie, gdzie „los całych ludów znajduje się często w rękach małych, ale znaczących grup ludzi”.

2 Konstytucja dogmatyczna o Kościele Lumen gentium, [w:] Sobór Watykański II. Konstytucje, Dekrety, Deklaracje. Tekst polsko-łaciński, Poznań 1967, 12.

Papież Franciszek, Discorso del Santo Padre.

Konstytucja Dogmatyczna o Kościele Lumen gentium, 12.

$5 \quad$ Konstytucja dogmatyczna Soboru Watykańskiego I Pastor Aeternus, rozdz. IV (Denz. 3074), Rzym 1875; por. także KPK 749, 1. 
Cieszę się, że ten numer „Studiów Teologii Dogmatycznej” włączył się w proces synodalnego dialogu przez refleksję nad samym pojęciem kolegialności i synodalności. W imieniu polskich teologów dogmatycznych, skupionych w Towarzystwie Teologów Dogmatyków, dziękuję ks. prof. Andrzejowi Proniewskiemu z Katedry Teologii Katolickiej Uniwersytetu w Białymstoku, redaktorowi naczelnemu czasopisma i redaktorowi prowadzącemu tego numeru, za wybranie właśnie tego tematu za temat główny tego numeru. Dziękuję wszystkim Autorom za wysoki poziom merytoryczny artykułów. Wszyscy wiemy, że zarówno kolegialność jak i synodalność Kościoła są dla nas ważnymi zadaniami do realizacji w Kościele trzeciego tysiąclecia. Zawarte w tym numerze „Studiów Teologii Dogmatycznej” teksty są istotnym krokiem w tym kierunku. 